\title{
Estratégias para a política florestal na Amazônia Brasileira - Algumas Informações Científicas
}

Instituto Nacional de Pesquisas da Amazônia, Manaus - AM

1 - Por suas características climáticas, elevada pluviosidade, abundância de radiação solar e inexistência de inverno a Amazônia apresenta um dos mais altos índices de produção da fitomassa do globo terrestre, operando por isso condições excepcionalmente favoráveis para programas de produção de energia de origem vegetal.

2 - A Amazônia terá seu equilíbrio ecológico perturbado, se um desflorestamento sistemático, em grande escala, sem reposição e sem planejamento, for praticado, havendo inclusive, o risco de provocar uma modificação climática de extensão desconhecida.

3 - O crescimento da concentração média de gás carbônico na atmosfera veio chamar a atenção dos pesquisadores para um problema sério e de características mais amplas. Acontece que, em geral, o planejamento da utilização dos recursos naturais é feito como se a atmosfera tivesse dimensão infinita e não pudesse ser alterada pela ação do homem em sua composição e na sua dinâmica.

4 - À medida que as florestas forem sendo substituídas por outro tipo de cobertura vegetal com menor biomassa (pastagens, cereais e outras culturas agrícolas) o carbono fixado passará em parte, do reservatório da biosfera para a atmosfera.

5 --- O efeito fundamental deste acréscimo será o aumento de temperatura da atmosfera com influência na hidrosfera e biosfera e o derretimento dos gelos acumulados nas calotas polares. Estimativas incicam que a destruição de $20 \%$ das reservas florestais, mantido o atual uso dos combustíveis fósseis, levará a um novo equilíbrio no qual o teor de $\mathrm{CO}_{2}$ será tal que a elevação da temperatura implicará num aumento da ordem de $10 \mathrm{~m}$ no nível dos oceanos.

6 - O desmatamento intensivo, sem reposição, produzirá uma modificação nos componentes do ciclo hidrológico e no tempo de residência da água no ecossistema. As enchentes serão mais violentas e nos períodos de seca, a vazão dos rios será menor que a atual.

7 - O aproveitamento dos recursos naturais da região se faz necessário através de uma agricultura racional, na qual uma utilização do solo com técnicas adequadas introduzirá modificações que poderão ser minimizadas. Com medidas conservacionistas, é possível aumentar o tempo de residência da água no solo e ao mesmo tempo diminuir os efeitos da lixiviação, da compactação e erosão. O planejamento agropecuário deverá ser feito tendo em vista o desenvolvimento das bacias hidrográficas, com a manutenção das florestas, em faixas de nível estratégicas. Sem a camada protetora das florestas, a estrutura do solo será facilmente destruída, e haverá erosão mais intensa pelas enxurradas. 
8 - A biomassa da floresta é o reservatório de nutrientes, sendo o solo em geral pobre em recursos minerais.

9 - A faixa de transição, entre cerrado e floresta, sendo ocupada por agropecuária vai delimitar nova área de transição para o norte, isto é, em direção à floresta. A paisagem botânica desta área ficará modificada.

10 - A fauna amazônica, além do seu valor no equilíbrio do ecossistema, tem importância econômica como fonte de alimentação humana, na economia extrativista e no turismo.

11 - Foi calculado que na África um leopardo vivo em habitat natural, produz recursos através do turismo, cerca de 100 vezes maiores que o obtido pela venda de sua pele.

12 - A diversidade da fauna e flora da Amazônia, no contexto dos ecossistemas naturais, só pode ser preservada por um sistema integral de Parques Nacionais e Reservas Equivalentes, cada qual suficientemente grande para incluir populações geneticamente estáveis de todas as espécies, inclusive daquelas que ocupam o topo de rede alimentar.

13 - A manutenção da biota amazônica será facilitada se for mantida uma área florestal primária, sem ser tocada e sem solução de continuidade ao longo de todos os rios, lagos e igarapés, em toda a Amazônia brasileira. Essa faixa contínua de floresta teria um alto valor no sentido de funcionar como corredor entre os Parques Nacionais e Reservas Florestais.

14 - Sistemas de manejo da floresta tropical, que permitam o melhor aproveitamento dos produtos naturais com o mínimo de perturbação das espécies e as suas interações, devem ser tentados através de um amplo programa de pesquisa, porque oferecem a maior probabilidade de auto sustentabilidade permanente destes recursos com as seguintes vantagens :

- manutenção intacta do "capital" biótico, tanto dos recursos explorados como dos outros ainda não utilizados;

- despesas de manejo e tratamento pós-exploratório sensivel. mente reduzidas;

- uma renda permanente.

15 - A exploração da floresta utilizando o processo de regeneração natural, através de técnicas especiais de extração da madeira, mostrou-se em outras regiões (Malásia e Trinidad) mais econômica e tecnicamente mais fácil do que o enriquecimento com mudas.

16 - Existem dificuldades técnicas de executar programas de replantio ou enriquecimento de florestas utilizando o plantio de mudas.

17 - A floresta amazônica, só será um recurso renovável se medidas especiais forem tomadas, durante a sua exploração. Não se conhece nenhuma experiência de grande escala, em que o ecossistema florestal tenha retornado às suas condições iniciais depois de devastado. A unidade florestal, no entanto, tem certos elementos que podem ser renovados de uma maneira sustentável com um sistema adequado de manejo. O reflorestamento da Amazônia com essências nativas é dificultado até agora pela obtenção de sementes. 
18 - As atividades do setor primário que mais têm devastado a floresta são a pecuária incentivada e agricultura itinerante.

19 - A despeito das vantagens que a região oferece, para o desenvolvimento da indústria florestal, a mesma é ainda subdesenvolvida e basicamente alicerçada no extrativismo sem manejo ou reposição, de maneira ídêntíca ao observado no passado remoto.

20 - As causas principais do desmatamento são:

- ausência de modalidade de manejo que garanta a exploração econômica da floresta em bases sustentáveis;

- incentivos fiscais com fiscalização inadequada;

- sistema de posse baseado em desmatamento;

- preço baixo de terra dá motivo a especulação, usos extensivos e ou não sustentáveis;

- necessidade de terra agrícola para sustentar a população crescente;

Qualquer programa de controle de desmatamento vai acabar em fracasso, caso não trate dessas causas fundamentais de desmatamento.

21 - As causas principais do não cumprimento do atual Código Florestal, e que devem ser levadas em conta na formulação de novas leis florestais, são:

- tradição antiga de desprezar leis de conservação da natureza;

- o contexto de um sistema jurídico extremamente flexível, caracterizado por aplicação seletiva das leis e por desvio do sistema formal;

- pessoal e recursos insuficientes no campo, devidos, em parte, à super-centralização de burocracias governamentais .

22 - Nas áreas de colonização, apesar de existir legislação que proíbe o desmatamento de mais que $50 \%$ de uma propriedade, não há fiscalização. Também existe muito desmatamento ao longo de cursos d'água, que é ilegal.

23 - No Acre e Rondônia, estão queimando diversas essências de valor econômico, face ao estímulo dos incentivos fiscais, para implantação de campos de pastagem.

24 - Mesmo sendo subdesenvolvido, o setor madeireiro é um dos componentes importantes na economia regional para a geração de renda e manutenção do emprego.

25 - O número de pessoas que podem ser sustentadas pelos diferentes projetos, depende do tipo de colonização, do tipo de tecnologia produtiva empregada, do padrão de vida a ser desfrutado pela população, das probabilidades de falha, em termos de diferentes critérios, consideradas aceitáveis pelos planejadores. O fato de que planejadores não disponham de (e não exijam) informações concretas sobre capacidade de suporte, implica em grande perigo de falha nos planos, tanto do ponto de vista de sustento da população humana a um padrão adequado, como do ponto de vista de evitar degradação do meio ambiente. 
26 - Um dos problemas na colonização da Amazônia é o abastecimento dos colonos com proteína animal. Geralmente, os projetos de colonização são realizados nas margens de rodovias. Essas rodovias atravessam áreas com igarapés pobres em nutrientes, os quais, em condições naturais, têm conseqüentemente poucos peixes.

27 - Todas as vezes que o homem invade ou destrói a natureza, sem levar em consideração as suas interações biológicas, propicia surgimento de doenças infecto-contagiosas, parasitoses e condições favoráveis para criação e dispersão de vetores.

28 - Abertura de novas estradas em áreas endêmicas ampliará o foco de certas doenças como: Leishmaniose, Malária, Oncocercose e Mansonelose. As duas últimas possuem zona bem delimitada na Ama. zônia, portanto, de fácil controle.

29 - O surgimento de águas estagnadas proporciona criadouros ideais para as larvas dos vetores da malária, febre amarela, etc...

30 - Com abertura de estradas, estaremos propiciando a penetração de parasitas e vetores de certas doenças como Doença de Chagas, Esquistossomose e Kalazar, que até o presente momento, aparentemente não existem na região, no que se refere à infecção humana.

31 - Os alimentos, a água e os dejetos humanos são os fatores principais na propagação das doenças gastrintestinais.

32 - A escassez de pessoal treinado para o diagnóstico e tratamento da Hanseníase, agrava o aglomerado de Hanseniano e aumenta o número de doentes. Este problema é facilmente resolvido quando na formação de novas comunidades é feito o exame dermatológico de $6 \mathrm{em}$ 6 meses.

33 - Espera-se que o "land rush" (em áreas de colonização) não esmague as culturas indígenas, não somente pelas razões humanísticas, mas porque o indio tem muito para ensinar-nos. Ele tem uma convivência com o meio ambiente muito mais profunda e, a experiência cultural e ecológica dele tem grande valor.

34 - Atualmente, só existem duas instituições com Cursos de Pós-Graduação, com sete cursos na Amazônia, em comparação com 7 instituições e 52 cursos no Nordeste, 30 instituições com 392 cursos no Sudeste, 8 instituições e 84 cursos na região Sul e 2 instituições com 52 cursos no Centro-Oeste. 